\title{
IDENTIFICATION OF THE DOMAIN PROCESS INTERSECTIONS BETWEEN COBIT 4.1 AND COBIT 5 IN THE DETERMINATION OF IT GOVERNANCE ASSESSMENT
}

\author{
Widyatasya Agustika Nurtrisha \\ Sistem Informasi \\ Universitas Telkom, Bandung, Indonesia \\ telkomuniversity.ac.id \\ widyatasya@telkomuniversity.ac.id
}

\begin{abstract}
The implementation of information technology has an essential role in organizational development to support a business process. Currently, information technology is widely adopted by the organization. It is believed to help improve the efficiency of the ongoing business process so that IT management is needed in a more structured. Thus, need a guideline that can guide IT governance so it can be measured and utilized. COBIT is one of the frameworks that can utilize in providing IT governance guidelines for organizations, and it is the main reference used in implementing IT governance in organizations. Still, the assessment process takes a long time because many processes are assessed. So conducted this research to determine the similar activities between COBIT 4.1 and COBIT 5 as the basis for determining the development of an organizational assessment process that the organization will carry out to see the efficiency of the assessed process domain. This research is focused on several organizations that have carried out IT governance assessments with COBIT 4.1 and will then implement the assessment process using COBIT 5. Still, it will usually take more time and effort if done separately to streamline the assessment process and identify domain intersects. The process from COBIT 4.1 and COBIT 5 so that the effort to carry out the assessment can be more streamlined. Thus, this research will produce a study result related to which activities intersect with each other to determine the IT governance assessment in an organization.
\end{abstract}

Keywords: COBIT, assessment, domain process, IT governance.

Intisari- Penerapan teknologi informasi memiliki peran penting dalam pengembangan organisasi untuk mendukung proses bisnis. Saat ini, teknologi informasi banyak diadopsi oleh organisasi. Hal tersebut diyakini dapat membantu meningkatkan efisiensi proses bisnis yang sedang berjalan sehingga dibutuhkan pengelolaan TI secara lebih terstruktur. Oleh karena itu, diperlukan suatu pedoman yang dapat memandu tata kelola TI agar dapat diukur dan dimanfaatkan. COBIT merupakan salah satu framework yang dapat dimanfaatkan dalam memberikan pedoman tata kelola TI bagi organisasi, dan menjadi acuan utama yang digunakan dalam penerapan tata kelola TI di organisasi. Namun, proses penilaiannya memakan waktu lama karena banyak proses yang dinilai. Maka penelitian ini dilakukan untuk mengetahui kesamaan aktivitas antara COBIT 4.1 dan COBIT 5 sebagai dasar penentuan pengembangan proses asesmen yang akan dilakukan organisasi serta melihat efisiensi domain proses yang dinilai. Penelitian ini difokuskan hanya pada sebagian organisasi yang telah melakukan asesmen tata kelola TI dengan COBIT 4.1 dan kemudian akan menerapkan proses asesmen menggunakan COBIT 5. Namun, biasanya akan membutuhkan lebih banyak waktu dan tenaga jika dilakukan secara terpisah sehingga perlu untuk mengefektifkan proses asesmen dengan mengidentifikasi irisan dari setiap domain proses dari COBIT 4.1 dan COBIT 5 sehingga upaya untuk melakukan asesmen dapat lebih disederhanakan. Dengan demikian, penelitian ini akan menghasilkan suatu hasil kajian terkait aktivitas mana yang saling beririsan untuk menentukan asesmen tata kelola TI dalam suatu organisasi.

Kata Kunci: COBIT, asesmen, proses domain, tata Kelola TI.

\section{INTRODUCTION}

Human dependence on information technology, sue an organization both private and government to align with business functions and IT functions in carrying out the internal and external development of the organization. Information technology becomes important in supporting each organization's business processes, and utilizing information technology can be used as a basis for leaders of organizations or stakeholders in making decisions and have an important role in the organization. Information technology is a necessity in organizations because it allows benefits to provide a competitive advantage. The influence of 
the development of information technology on the organization that is on activities in an organization related to the factors of application and information technology benefits derived from the people, process, and technology of an organization that in implementing IT facilities supports the operational activities of the organization. Every company needs to align its organizational goals with IT goals to get maximum support from its developed information system (Sandfreni and Adikara 2018).

IT governance focuses on information technology systems and organizational performance and risk management to fulfill current and future business needs, both from an internal and external business perspective (Miranti 2019). The governance process ensures that the company's objectives are optimally achieved by evaluating stakeholder needs, conditions, options and setting direction by prioritizing and monitoring performance against the agreed objectives (Andry and Setiawan 2019)| IT governance needs to have good quality and can be measured to achieve an optimal organizational goal so that it needs a framework or general guidelines (best practice) that can provide a guide to good IT governance, so can be utilized and managed to gain competitiveness or organizational competitive advantage, to improve resources related to information technology, so that existing IT assets can be managed more optimally. a framework that can be adopted in the management of IT governance, one of which can adopt the Control Objective for Information and Related Technology (COBIT). The COBIT framework has evolved with different characteristics from each version. The process of measuring COBIT 4.1 uses a maturity level called Capability Maturity Model. This model is used to measure the maturity of the current conditions of IT processes within an organization. COBIT 5 has the assessment process which is called the Process Capability Model and this model measures the governance process and identifies processes that need to be improved in performance by looking at the level of capability.

Information Technology (IT) is not only seen as supporting business processes in operational effectiveness and efficiency. However, it has been seen as a proponent of business strategy to achieve organizational goals (Tristiyanto and Octaria 2019). Every organization that is established must have a goal for organization. To achieve this goal, all stages of the process carried out must be planned, and to determine whether the activities carried out following the plan need to be controlled and supervised (Murad et al. 2018). Suppose the organization does not sufficiently support the application of information technology. In that case, it will affect competitive advantage in the management of IT governance starting from the planning process to its implementation because IT governance is mutually integrated from the organizational structure, so it is necessary to ensure that the application of IT organizations must be able to support and expands the strategy and goals of the organization (ISACA. and Lainhart 2012), stated by (Indrajit 2013) on the concept of IT governance in Gartner's Integrated Planning Suite that there are four aspects of a governance framework that are interrelated with one another about the principles of governance that want to be upheld, these aspects include strategic planning, enterprise architecture, and portfolio management principles. Then the related research according to (Suroso and Rahadi 2017) and (Anindra et al. 2018) is about the proposed IT governance model that focuses on the objectives of the business strategy and organizational IT objectives concerning previous IT governance.

The COBIT 4.1 (Control Objective for Information and related Technology) method consists of domains and processes used to manage activities and logical structures (Dazki, Islami, and Atmojo 2020), with which the measurement process is familiar with using an assessment based on a maturity model. The process of measuring COBIT 4.1 uses maturity levels, with Capability Maturity Model (CMM), this model is used to measure the maturity of the current conditions of IT processes within an organization. The maturity Model in COBIT 4.1 is a model to measure the maturity level of information technology management in an organization by considering and using internal controls (Anderson, Kevin, and Andry 2018).

The other version of COBIT which has undergone development with the previous version that is adapted to the development of IT is COBIT version 5 , because of the development of IT, it is necessary to adjust to the framework adopted, especially in the assessment process. COBIT 5 is a framework from the Information Systems Audit and Control Association (ISACA) that aims to guide IT governance, maximize enterprise management, manage IT risk and security, and ensure public recognition (Astuti et al. 2017). In COBIT 5 assessments were made based on ISO / IEC 15504 which is called the Process Capability Model (PCM). This model measures governance processes that need to be improved in performance by the level of capability of the process, this model has six levels of capability, starting from Level 0 (Incomplete Process) to Level 5 (Optimizing Process) (PatónRomero et al. 2018).

The process to determine a suitable model for assessing IT governance on the characteristics of the process based on one or more reference models 
is the concept of an assessment model that is applied to measuring an organization's maturity. It helps align business functions with organizational IT that can provide direction for the organization on the points that need to be achieved in each activity to support the organization's success to ensure control related to IT and how the organization achieves its business goals. Related to the discussion of IT governance, there is literature research related to the implementation of IT governance and the design of a framework for IT governance, especially in Indonesia.

Table 1. Literature Research Related IT Governance Assessment

\begin{tabular}{|c|c|c|c|}
\hline Title/Year & Researcher & Framework & Output \\
\hline $\begin{array}{l}\text { Determining } \\
\text { Evaluated Domain } \\
\text { Process through } \\
\text { Problem } \\
\text { Identification } \\
\text { using COBIT } 5 \\
\text { Framework }\end{array}$ & $\begin{array}{l}\text { Fitroh et al. } \\
2017\end{array}$ & COBIT 5 & $\begin{array}{l}\text { Proposed } \\
\text { Model }\end{array}$ \\
\hline $\begin{array}{l}\text { Assessment of } \\
\text { Capability Level } \\
\text { and IT }\end{array}$ & $\begin{array}{l}\text { Ekanata and } \\
\text { Girsang } 2017\end{array}$ & $\begin{array}{l}\text { COBIT } 5 \text { and } \\
\text { ITIL V3 }\end{array}$ & $\begin{array}{l}\text { Evaluation } \\
\text { / Audit } \\
\text { Model }\end{array}$ \\
\hline
\end{tabular}

Governance

Improvement

Based on COBIT

and ITIL

Framework at

Communication

Center Ministry of

Foreign Affairs

\begin{tabular}{llll}
\hline Adopted COBIT-5 & Putra et al. 2017 & COBIT 5 & Evaluation
\end{tabular}

Framework for

System Design of

/ Audit

Indonesia Navy

IS/IT: An

Evaluation

\begin{tabular}{|c|c|c|c|}
\hline $\begin{array}{l}\text { Maturity } \\
\text { Evaluation of } \\
\text { Information } \\
\text { Technology } \\
\text { Governance in PT } \\
\text { DEF Using Cobit } 5 \\
\text { Framework } \\
(2017) \\
\end{array}$ & $\begin{array}{l}\text { Putri, } \\
\text { Aknuranda, and } \\
\text { Mahmudy } 2017\end{array}$ & COBIT 5 & $\begin{array}{l}\text { Evaluation } \\
\text { / Audit } \\
\text { Model }\end{array}$ \\
\hline $\begin{array}{l}\text { Implementation of } \\
\text { COBIT } 5 \\
\text { Framework for } \\
\text { Academic } \\
\text { Information } \\
\text { System Audit } \\
\text { Perspective: } \\
\text { Evaluate, Direct, } \\
\text { and Monitor } \\
(2018)\end{array}$ & $\begin{array}{l}\text { Murad et al. } \\
2018\end{array}$ & COBIT 5 & $\begin{array}{l}\text { Evaluation } \\
\text { / Audit } \\
\text { Model }\end{array}$ \\
\hline $\begin{array}{l}\text { Improving the } \\
\text { Quality of } \\
\text { Enterprise IT } \\
\text { Goals using COBIT } \\
5 \text { Prioritization } \\
\text { Approach }(2018)\end{array}$ & $\begin{array}{l}\text { Anindra et al. } \\
2018\end{array}$ & COBIT 5 & $\begin{array}{l}\text { Proposed } \\
\text { Model }\end{array}$ \\
\hline
\end{tabular}

Based on some of the literature research, it can be seen that the previous research was more about discussing the level of organizational maturity and the application of the COBIT framework to help measure IT governance. In contrast, this study produced study results related to identifying fact items and activities in the framework. And designing an appropriate IT governance assessment guide for organizational needs with measurement results based on maturity and capability models that aim to determine the efficiency of the domain process for the assessment process. There is still no research that discusses the intersection between the process domains in COBIT 4.1 and COBIT 5; this is done to streamline the measurement process by translating the control objective in COBIT 4.1 to the COBIT 5 process domain.

In the COBIT 4.1 and COBIT 5 frameworks, there is a clear distinction between governance and management. Governance is the responsibility of stakeholders by implementing the EDM process domain (Evaluate, Direct, Monitor). While in view, management carries out responsibilities based on a plan, build, run, monitor (ISACA 2012). The gaps of process area that can be seen between each of these frameworks are described in Table 2 below.

Table 2. Difference between COBIT 4.1 and COBIT 5

\begin{tabular}{ccc}
\hline Category & COBIT 4.1 & COBIT 5 \\
\hline Domain Area & 4 & 5 \\
\hline Driver & Best Practice & $\begin{array}{c}\text { Stakeholder } \\
\text { Expectation }\end{array}$ \\
\hline Process Area & 34 & 37 \\
\hline Framework & COBIT 4.1 & $\begin{array}{c}\text { COBIT 4.1, Val IT, } \\
\text { Risk IT }\end{array}$ \\
\hline Enablers & - & 7 Enablers \\
\hline Assessment Model & Maturity Model & Capability Model \\
\hline
\end{tabular}

Based on table 2, there are differences between COBIT 4.1 and COBIT 5, especially in the assessment model, so it is necessary to identify the domain process in each framework.

There is justification for the possibility of several similar activity items in each process domain in each framework, thus the need for identification of several activity items so that it can streamline the assessment process to be carried out. So it is necessary to identify several similar activity items to see the interrelationship between activities existing in each process domain so that it becomes the basis for conducting an assessment of an organization's IT governance by looking at related activities. So that the efforts in the assessment process become more efficient for assessing IT governance so that the organization can accommodate related and intersect items of activity.

\section{MATERIALS AND METHODS}

According to Wiley Heyden, that Research methodology in information technology systems is science by using stages of planning with several methods, techniques, tools, and documentation. The research methodology used adopts Design Science 
Research methodology guidelines. The methodology begins with identifying problems, defining solutions, designing and building designs to the evaluation stage; this is stated in K. Peffers' journal entitled A Design Science Research Methodology for Information Systems Research. The stages of this research are described in sequential stages.

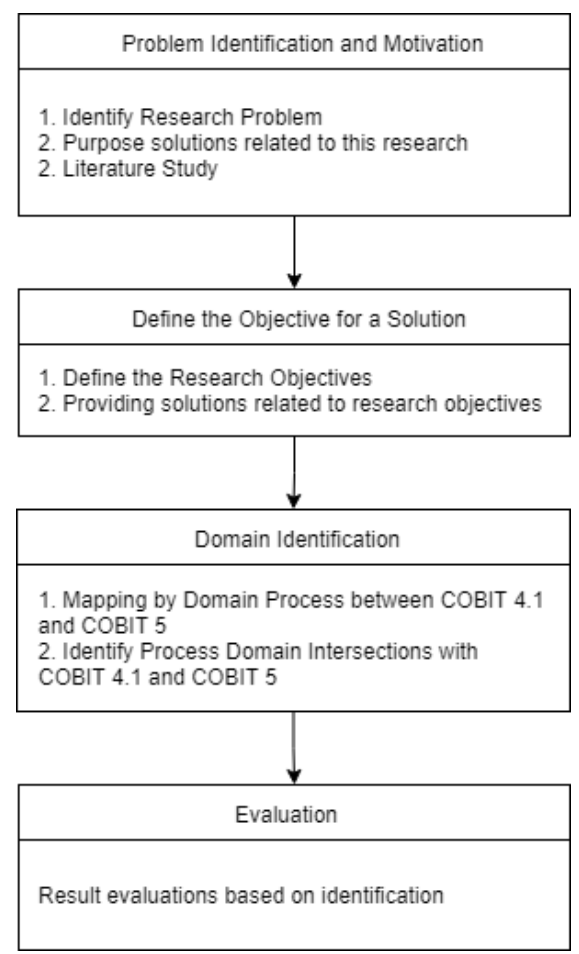

Figure 1. Research Methodology Steps

The description of the stages of research based on Figure 1 is as follows:

1. Problem Identification and Motivation

At this stage, the problem identification is carried out and the problem formulation is related to the research (research problem) which then from the formulation of the problem will become the main problems.

2. Define the Objective for a Solution

At this stage, analysis is carried out in the design of developing IT governance assessment. The analysis carried outcomes from a literature study. The research concepts studied in the design of developing IT governance assessments include,

- Identify fact items in process activities with related domains in each framework used (COBIT 4.1 and COBIT 5).

- Guidance for assessing maturity and capability levels in measuring information technology governance in each process domain by adopting measurement development.
- $\quad$ Research relating to information technology governance and measurement.

3. Domain Identification

The stages of Domain Identification related to the assessment are explained in detail with the structure of Input, Tool, Technique, Output (ITTO) presented in Table 2 below.

Table 3. Structure Regarding IT Governance Assessment Study

\begin{tabular}{ll}
\hline Input & $\begin{array}{l}\text { COBIT 4.1, COBIT 5, and related } \\
\text { literature }\end{array}$ \\
\hline Tool & $\begin{array}{l}\text { The analysis table identifies process } \\
\text { domains and related activities. }\end{array}$ \\
\hline & - Conduct studies and analyzes of \\
& components of the COBIT \\
& framework. \\
& Identify IT processes and \\
& domain-related process mapping. \\
Technique & Identification of fact items and \\
& related activities in each COBIT \\
& 4.1 and CoBIT 5 framework. \\
& Develop an IT governance \\
& assessment. \\
\hline \multirow{3}{*}{ Output } & $\begin{array}{l}\text { Development of assessment and } \\
\text { study results related to the IT } \\
\text { governance assessment process. }\end{array}$ \\
\hline
\end{tabular}

4. Evaluation

At this stage, the evaluation is carried out by validating the identification of process activities to find out the suitability of the intersect activities in each process domain.

\section{RESULTS AND DISCUSSION}

This research focuses on COBIT versions 4.1 and 5 because both versions have measurement results with different models, on COBIT 4.1 the measurement process is done by mapping the level of maturity that assesses the existence of the level of IT management with maturity models, while the COBIT 5 process refers to the ISO 15504 standard which adopts the level of organizational capability with the capability model. Therefore, it is necessary to identify activities that are related or covered in each framework, this aims to streamline the assessment process so that once the assessment process will get the results of measurement of maturity and capabilities as well.

Each IT process in COBIT has a detailed control objective that defines the activities of each process which is a control tool of the IT process. The first thing to do is to map the process domains between each framework to define which process domains are interrelated.

\section{A. Identify Related Process Domain}

The initial step in developing the measurement process development of each activity is by adjusting the COBIT model so that the 
assessment process is integrated between the process in version 4.1 with CMM-based results and version 5 with PCM. This adjustment process is needed to adjust the framework with the appropriate outputs of the assessment results to meet the level of maturity and capability of the organization so that it is necessary to identify processes in each domain.

This mapping process aims to map the process domains of each COBIT framework to know the relationship between the process domain in COBIT 4.1 and the process domain in COBIT 5. In COBIT 4.1, there are 34 processes which will later be mapped into 37 processes in COBIT 5; These processes are obtained based on the control objectives in COBIT 4.1 , whose processes are related and covered in each process domain in COBIT 5 so that this mapping becomes a reference for processes that can be carried out simultaneously in the assessment or measurement process to produce a level of organizational maturity and capability. These are contained in the COBIT manual in the Cross Reference Appendix A in COBIT 5 Enabling Process Book (Mapping the legacy ISACA Framework).

\section{B. Control Objective Identification}

Control objectives are part of the details of the IT process in COBIT 4.1. In conducting the IT governance measurement design process that adopts the COBIT framework, the assessment process focuses on activities and facts in control objectives. Each of the IT processes in COBIT 4.1 has detailed control objectives that define the activities of each process which are the control tools of the IT process, so it is necessary to identify control objectives for each process domain. Mapping process between the control objectives of COBIT 4.1 and the COBIT 5 subprocess. It can be referred to as key management practice, which is used as a reference for the implementation of IT governance.

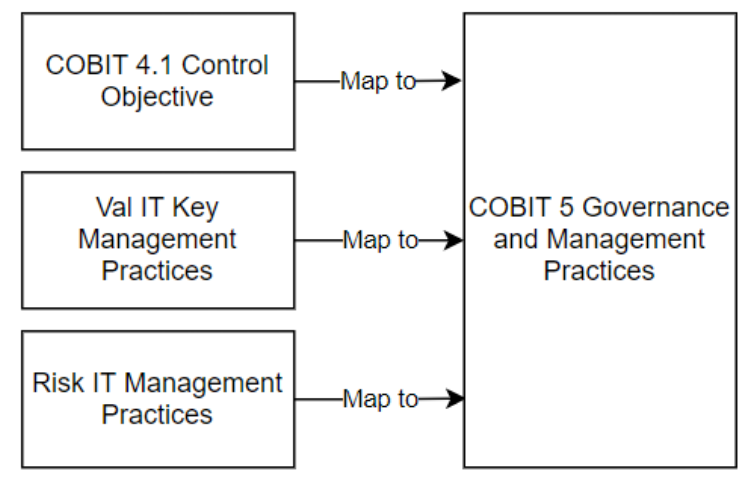

Figure 2. COBIT 4.1 Control Objective Mapped to COBIT 5

This mapping provides an overview of the relationship to each process domain in each framework of how each process domain can relate to one another between activities that are a control tool in the IT process. For each domain, each of the one processes was taken to identify processes related to the sub-processes in COBIT 5. In carrying out these assessment activities, some procedures need to be carried out or executed to obtain the results desired by the organization; to streamline the assessment process carried out, it is necessary to identify the related processes wherein each process domain there is a procedure that provides an overview of the activities that must run in any specific process domain.

\section{Identification of Similar Process Activities}

After obtaining the identification results of the COBIT 4.1 process domain covered in COBIT 5 (the mapping is taken from the COBIT 5 Enabling Process guide regarding the mapping between COBIT 5 and the legacy ISACA Framework), one of which is to map certain process domains between COBIT 4.1 and COBIT 5, then is to determine similar process activities in each framework, in this case, COBIT 4.1 and COBIT 5, what is needed is to identify intersects based on activities and facts in the related process domain. As an example of an activity/fact, that has an intersection in each process domain in each framework, not all process domains are identified; the example given focuses on the P01, P05, AI1, AI5, DS6, DS7, ME1, ME3 process covered in the process sub-domain in COBIT 5. The mapping carried out between some of the process domains contained in COBIT 4.1 and COBIT 5 is based on the suitability of the facts and the suitability of the evidence contained in both, the suitability of facts and evidence obtained from COBIT 4.1 control objectives and COBIT 5 management practice as well as for the suitability of the outputs included in the COBIT 4.1 control objective and COBIT 5 management practice. Activities/facts are contained in the COBIT 4.1 management guideline and the COBIT 5 process reference guide. So that during the assessment measurement process in a company or organization, it is hoped that it does not need to take an enormous effort. It will be more efficient in terms of time and process in assessing conducting a separate assessment, by only identifying points in the process domain identified in previous assessments. If a company or organization has already conducted an assessment using COBIT 4.1, then refer to the assessment regarding COBIT 5. The figure below is a description of the linkage of the process domain intersection that has been identified based on the suitability of activity/fact items and the outputs produced based on the COBIT 4.1 management guideline and COBIT 5 process reference guide shown in Figure 3 to Figure 6. 


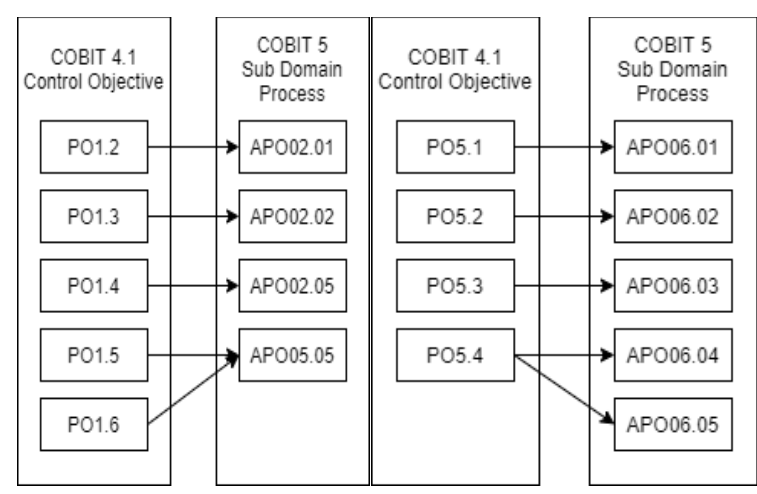

Figure 3. Mapping P01-5 with COBIT 5 Sub Domain Process

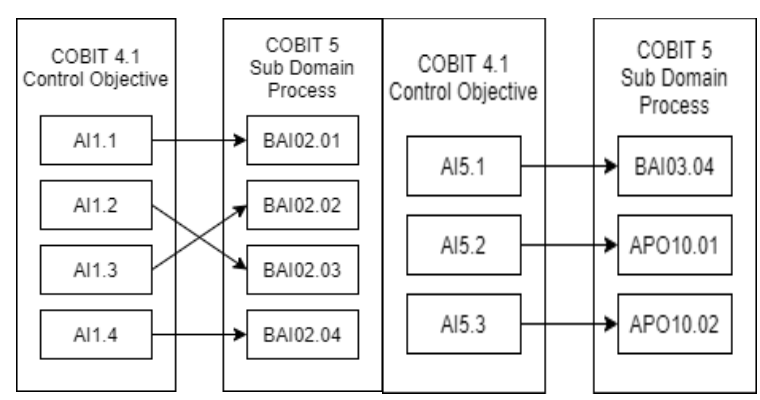

Figure 4. Mapping AI1-5 with COBIT 5 Sub Domain Process

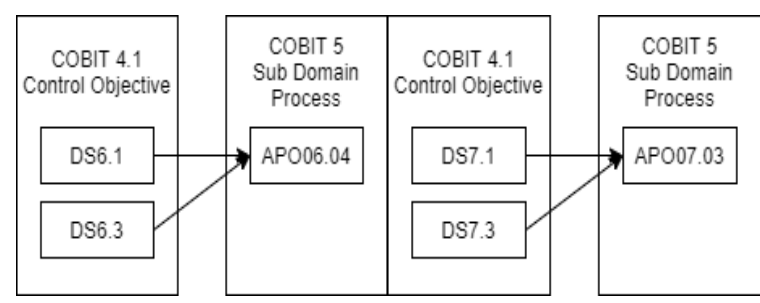

Figure 5. Mapping DS6-7 with COBIT 5 Sub Domain Process

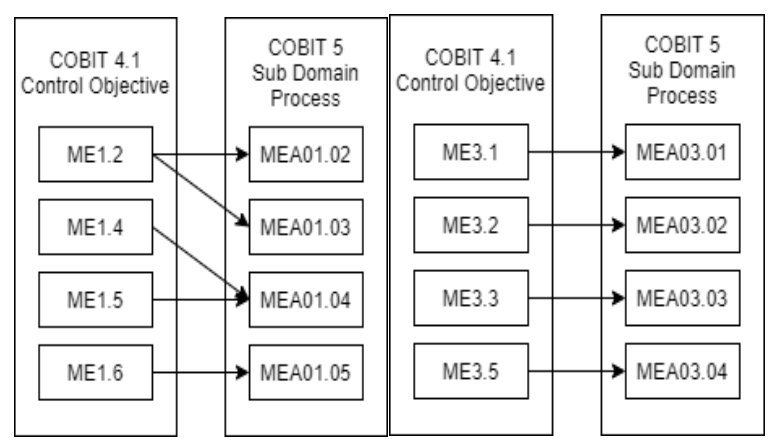

Figure 6. Mapping ME1-3 with COBIT 5 Sub Domain Process

Identification of domains process was obtained based on the suitability of activities and facts in each domain; The interrelated processes of each process domain will be the basis for developing an IT governance assessment, which later was expected to be more efficient in measuring IT governance applied in the organization so that organizations can refer to any COBIT 4.1 process related to $\operatorname{COBIT} 5$, this is done if there is an organization that will migrate to COBIT 5 or if the organization wants to get a measurement with two measurement results at once.

For the measurement of IT governance, the organization still refers to the assessment of maturity and capability and does not change the way of measurement, so that in this case the identification of the process domain is only to know as effectively and efficiently as if it already knows what activities are similar so there are no need to conduct an assessment of initially, but for nonintersecting domains, the assessment still follows the usual procedure and evidence collection.

\section{Validation of Process Domain Identification}

Evaluation of the design of the development process of the measurement of information technology governance uses a validation technique by utilizing the intersection of measurement results to support the evaluation process of measurement development. This evaluation technique also takes into account several processes in examining linkages to similar processes. The validation process is expected to be able to build justification coherently. This validation aims to find out the suitability between the activities that have been identified based on each process domain. The process of measuring IT governance that has been identified is validated to see compliance with the requirements in the assessment process.

\section{Table 4. Process Domain Identification Process}

\begin{tabular}{ll}
\multicolumn{1}{c}{ Validation } \\
\hline $\begin{array}{l}\text { Requirements } \\
\text { Control Objective with COBIT } \\
\begin{array}{l}5 \text { Management Practice } \\
\text { subprocess. }\end{array}\end{array}$ & $\begin{array}{l}\text { Cross Reference } \\
\text { Appendix a Mapping the } \\
\text { legacy ISACA Framework. }\end{array}$ \\
\hline $\begin{array}{l}\text { The suitability of several } \\
\text { activities in a COBIT 4.1 } \\
\text { process domain to the COBIT }\end{array}$ & $\begin{array}{l}\text { COBIT 4.1 control } \\
\text { objective and COBIT 5 } \\
\text { management practice. }\end{array}$ \\
\hline $\begin{array}{l}\text { The suitability of the output } \\
\text { of each process domain that } \\
\text { is included in each activity in } \\
\text { a particular process. }\end{array}$ & $\begin{array}{l}\text { COBIT 4.1 management } \\
\text { guideline and COBIT 5 } \\
\text { process reference guide. }\end{array}$ \\
\hline $\begin{array}{l}\text { The suitability of assessment } \\
\text { between activities in a } \\
\text { particular process domain }\end{array}$ & $\begin{array}{l}\text { Presented in figure 2 } \\
\text { until figure 5. }\end{array}$ \\
\hline
\end{tabular}

\section{CONCLUSION}

The conclusion that can be obtained in this study is that this study produces a study result on the possibility of several similar and intersecting activity items in each process domain in COBIT 4.1 and COBIT 5 , based on the results of the process domain identification carried out, each of the two processes taken on each domain in COBIT 4.1 that 
represents the whole process. This study aims to determine what process domains have similar activities so that it is expected that if there are organizations that have conducted assessments with COBIT 4.1 and will migrate to COBIT 5, then they do not need more effort for the assessment again and only refer to activities that were measured in previous assessments, as well as this research to find out the effectiveness and efficiency of IT governance assessment that refers to the identification of intersecting activities. Based on the limitations of the study, for further research development are to be able to produce a complete and comprehensive conclusion, it is necessary to identify activities that are in other process domains outside the activities that have been identified in this study, and in addition to identifying items of intersecting activities, it is also necessary to ensure the subset of the COBIT 4.1 process that is covered in COBIT 5.

\section{REFERENCE}

Anderson, Ricky, Kevin Kevin, and Johanes Fernandes Andry. 2018. "Audit Aplikasi Inventori Menggunakan Framework Cobit 4.1 Pada Store Nonna." It Journal Research and Development 3(1):1-12. doi: 10.25299/itjrd.2018.vol3(1).1605.

Andry, Johanes Fernandes, and Ari Kurnia Setiawan. 2019. "It Governance Evaluation Using Cobit 5 Framework on the National Library." Jurnal Sistem Informasi 15(1):10-17. DOI: 10.21609/jsi.v15i1.790.

Anindra, Firman, Bahtiar Saleh Abbas, Agung Trisetyarso, Wayan Suparta, Chul Ho Kang, and Harco Leslie Hendric Spits Warnars. 2018. "Improving the Quality of Enterprise IT Goals Using COBIT 5 Prioritization Approach." 2018 International Conference on Information and Communications Technology, ICOIACT 2018 2018-January(April):270-74.

DOI: 10.1109/ICOIACT.2018.8350814.

Astuti, Hanim Maria, Feby Artwodini Muqtadiroh, Eko Wahyu Tyas Darmaningrat, and Chitra Utami Putri. 2017. "Risks Assessment of Information Technology Processes Based on COBIT 5 Framework: A Case Study of ITS Service Desk." Procedia Computer Science 124:569-76.

DOI: 10.1016/j.procs.2017.12.191.

Dazki, Erick, Zaenab Islami, and Wahyu Tisno Atmojo. 2020. "Pengukuran Maturity Level Tata Kelola Teknologi Informasi Menggunakan Framework Cobit 4.1 Pada Pt. Dinamika Mitra Sukses Makmur." Jurnal Inovasi Informatika 5(1):35-44. doi: 10.51170/jii.v5i1.31.

Ekanata, Ardly, and Abba Suganda Girsang. 2017.
"Assessment of Capability Level and IT Governance Improvement Based on COBIT and ITIL Framework at Communication Center Ministry of Foreign Affairs." International Conference on ICT For Smart Society (ICISS).

Fitroh, Sahbani Siregar, and Eri Rustamaji. 2017. "Determining Evaluated Domain Process through Problem Identification Using COBIT 5 Framework." 2017 5th International Conference on Cyber and IT Service Management, CITSM 2017 (August). DOI: 10.1109/CITSM.2017.8089281.

Indrajit, Richardus Eko. 2013. "Kerangka Investasi Gartner." 5(C):1-5.

ISACA., and J. W. Lainhart. 2012. COBIT 5: A Business Framework for the Governance and Management of Enterprise IT COBIT 5. Vol. 34.

ISACA. 2012. Enabling Processes.

Miranti, Alfia. 2019. "Evaluasi Tata Kelola Teknologi Informasi Menggunakan Framework COBIT 5." Jakarta: UIN Syarif Hidayatullah.

Murad, Dina Fitria, Erick Fernando, Muhamad Irsan, Raymondus Raymond Kosala, Benny Ranti, and Suhono Harso Supangkat. 2018. "Implementation of COBIT 5 Framework for Academic Information System Audit Perspective: Evaluate, Direct, and Monitor." Proceedings of ICAITI 2018 - 1st International Conference on Applied Information Technology and Innovation: Toward A New Paradigm for the Design of Assistive Technology in Smart Home Care 102-7. DOI: 10.1109/ICAITI.2018.8686700.

Patón-Romero, J. David, Maria Teresa Baldassarre, Moisés Rodríguez, and Mario Piattini. 2018. "Green IT Governance and Management Based on ISO/IEC 15504." Computer Standards and Interfaces 60(January):26-36. doi: 10.1016/j.csi.2018.04.005.

Putra, I. Nengah, Abdul Hakim, Sholeh H. Pramono, and Herman Tolle. 2017. "Adopted COBIT-5 Framework for System Design of Indonesia Navy IS/IT: An Evaluation." International Journal of Applied Engineering Research 12(17):6420-27.

Putri, Mayang Anglingsari, Ismiarta Aknuranda, and Wayan Firdaus Mahmudy. 2017. "Maturity Evaluation of Information Technology Governance in PT DEF Using Cobit 5 Framework." Journal of Information Technology and Computer Science 2(1):19-27. DOI: $10.25126 /$ jitecs.20172123.

Sandfreni, and Fransiskus Adikara. 2018. "Capability Level Assessment of IT Governance in PTP Mitra Ogan: COBIT 5 Framework for BAI 04 Process." Proceedings of the 2017 4th International Conference on 
Computer Applications and Information Processing Technology, CAIPT 2017 2018January:1-5.

DOI: 10.1109/CAIPT.2017.8320665.

Suroso, Jarot S., and Bayu Rahadi. 2017. "Development of IT Risk Management Framework Using COBIT 4.1, Implementation in IT Governance for Support Business
Strategy." International Conference on Education and Multimedia Technology.

Tristiyanto, and C. Octaria. 2019. "IT Governance Audit at Lampung University Using COBIT 5 Framework Focus on EDM Domain." Journal of Physics: Conference Series 1338(1). DOI: 10.1088/1742-6596/1338/1/012060. 